\title{
JUSTICE FOR CHILDREN IN ARGENTINA: A BACKLASH TO CONSERVATIVE DISCOURSES
}

\author{
YAMILA VANESA RODRIGUEZ ${ }^{1}$ \\ ${ }^{1}$ University of Buenos Aires, Department of Law, Avenida Figueroa Alcorta 2263 (1425), Buenos Aires, \\ Argentina. ORCID: 0000-0001-9902-275X, Email: yamila.vanesa.rodriguez@gmail.com
}

\begin{abstract}
The author uses Critical Discourse Analysis to compare two legal documents of critical relevance for the rights of children in conflict with the law in Argentina: the current law no. 22,278, called Régimen Penal de la Minoridad, and the project named Sistema de Responsabilidad Penal Juvenil which was under consideration by the National Congress during 2019. This project was proposed by the government so as to establish a new juvenile justice system in Argentina, following a widely spread tendency in the Latin American region. The purpose of the article is to show that, even though the language of human rights is used in official discourse and in the legal text submitted to Parliament, many of its features represent a clear backlash to a more conservative regime.

KEYWORDS: juvenile justice, critical discourse analysis, human rights, children's rights, Latin America
\end{abstract}

\section{INTRODUCTION}

In Latin America, and particularly in Argentina, the media and the public discourse pay a lot of attention to children in conflict with the law. It is said that children -the majority of whom are in a situation of socio-economic vulnerability- are violent and cruel, that they have no respect for institutions, and that they are not attached with 
the consequences of their acts. Therefore, in this understanding, if children commit a crime, they should be held responsible and punished as adults.

The bill that regulates the judicial procedure in cases of children in conflict with the law in Argentina - bill no. 22,278 Régimen Penal de la Minoridad (Minority Criminal Regime) [1] copies the U.S. model of juvenile courts. This model was introduced in Latin America in 1919 and is known in the region as the "Tutelary System". Under this model, youth crime had to be approached differently than adult crime, and the goal of the interventions on youth was supposed to be rehabilitation, not punishment.

The Tutelary System used to be a regional tendency. While at the beginning of the twentieth century Latin American laws conceived children and adolescents as subjects to be saved and treated, over the last thirty years -with the incorporation of international human rights law into domestic law-, the laws in many countries in the region have been modified with the argument that children and adolescents should be considered as rights bearers who have the same due process rights as adults and can be held criminally responsible, though subject to special regulations (Beloff \& Langer 2015). This was called the "Integral Protection System" or the "Rights System".

From a constitutional point of view, the Régimen Penal de la Minoridad bill has some important flaws. On one hand, it was enacted in 1980, during the last military regime in Argentina. Even though the legal doctrine has ratified the legislation passed during that period in order to ensure legal security [2], it can be argued that this piece of legislation lacks democratic legitimacy.

On the other hand, this bill was sanctioned nine years before the General Assembly of the United Nations adopted the Convention on the Rights of the Child (CRC). This is of paramount importance because, since 1994, this international instrument is part of the argentine legal system by its incorporation to the National Constitution [3].

This illegitimacy is even worse if we consider that a large group of the population -children-which is directly affected by these regulations, is normally left aside of public discussions because of the way in which society understands the meaning and purpose of citizenship. In traditional political theory, the citizen has been conceived as a person with capacities for public reason, autonomy or rational reflection and deliberation. Having these complex language-mediated capacities -which I will call (following Gary Steiner) "linguistic agency” (Steiner 2013) - determines whether a person is considered as a citizen with rights to participate in the political community or as a passive object to whom society owes duties of care (Donaldson \& Kymlicka 2016).

Including children in political participation requires us to rethink citizenship theory, and indeed democratic theory, from the ground up (Donaldson \& Kymlicka 2016). Although it is not the main purpose of this article, I will come back to the question about how power and decision-making are negotiated in these places and spaces between adults and children later.

International human right's institutions have urged Argentina to change the law in order to make it compatible with the CRC. For example, while considering the state's last report, the Committee on the Rights of the Child has inquired Argentina about "life imprisonment for juvenile offenders" and about the reason why detention of children was used as the first response (United Nations 2018). Also, the Inter-American 
Court of Human Rights has considered that life imprisonment for children was equal to torture and inhumane treatment and has found Argentina responsible for violating the right to be protected against torture (articles 5.2 of the American Convention on Human Rights and 37 of the CRC). Consequently, has ordered the State to change its legislation on that issue (Inter-American Court of Human Rights 2013).

However, there was never enough political momentum to undergo those required changes. This situation changed in early 2019, when the government sent to Congress a project about a new juvenile responsibility system entitled Sistema de Responsabilidad Penal Juvenil (Juvenile Criminal Responsibility System). In the explanatory statement sent to Congress, the government said, amongst other arguments, that this new bill comes to meet the requirement of the Inter-American Court of Human Rights that Argentina should adjust its legal framework to international standards in juvenile criminal justice. It also relies on the assumption that children should be responsible for their actions (Argentina 2019).

One of the main reasons stated for this legislative change is that it is the state's responsibility to maintain social peace and to respond to extreme cases of crimes committed by adolescents because of their extreme vulnerability. Likewise, the government has declared that this vulnerability must be also addressed by the state (Argentina 2019).

This preoccupation about children being involved in criminal activities does not seem to have a relation with an increase in juvenile crime rates, which appear to be descending over the last years. According to the information provided by Base General de Datos de Niños, Niñas y Adolescentes (General Data Base of Boys, Girls and Adolescents), an official institution that is a part of the Federal Supreme Court, in 2016, there were 1564 cases of children in conflict with the law; in 2017, 1520 and in 2018, 1493. In addition, in 2018, the immense majority of them were prosecuted because of crimes related to property and, in 2018 , only $1.08 \%$ were serious crimes e.g. assault and murder (Argentina 2016, 2017 \& 2018).

Therefore, the primary purpose of this article is to explore the way in which conservative discourses shapes official public response to children in conflict with the law in Argentina. I will demonstrate that, even though Children's Rights Discourse is used in official discourse and in the legal text submitted to Parliament, many of the features of the project represent a clear backlash to a more conservative regime.

For that purpose, firstly, I will explain the methodology used to conduct this research and my theoretical starting point. Secondly, I will summarize the results I obtained, and, after that, they will be discussed in light of the theoretical approach explained above. Finally, I will share my conclusions and some possible lines of investigation for future research.

\section{METHODOLOGY}

This brief research was conducted using MAXQDA software to analyze both the current law and the project. I have designed two colored codes: "Tutelary System" -in red - and "Rights System" - in yellow. Afterwards, I conducted a lexical search (both 
electronically and manually) for words and expressions related to those systems and coded them.

Under the Tutelary System code, lexical search was conducted to find the words imputabilidad (criminal responsibility), privación de libertad (imprisonment) and menor (minor), or some variations of those. Instead, under the Rights System code, the words protección (protection), medidas alternativas/educativas (alternative/educative measures) and niños, niñas y adolescentes (boys, girls and adolescents), or some variations of these, were searched.

Plus, Critical Discourse Analysis (CDA) theoretical framework was used both for designing the codes and for interpreting the data collected from the comparative legal study of the vocabulary used in the current bill no. 22,278 and the project about a new juvenile responsibility system. To do this, I followed Norman Fairclough`s approach in terms of considering that CDA is an analysis of the dialectical relationships between discourse (including language but also other forms of semiosis) and other elements of social practices. As a consequence, we cannot take the role of discourse in social practices for granted, it has to be established through analysis (Fairclough 2003). This analysis must start with the identification of social problems with at least some partially discursive aspect which could be researched by means of a situated analysis of texts (Fairclough 2003).

Although legal scholars are not very familiar with qualitative research methods, both legal and discourse analysis concern reading and interpreting texts, both are preoccupied with the meaning of texts, and both seem to assume that texts have a life of their own that is independent of their authors. Law is, after all, an inherently societal discourse, whereas quite a specific one. Therefore, it seems appropriate to look at those sociological methods that analyze how language is used by, and in relation to, law and its institutions (Niemi-Kiesilainen, Honkatukia \& Ruuskanen, 2007).

Using CDA approach was fruitful for the analysis of legal discourse and for an understanding of the relationship between what is normative and what is factual, and what lies beneath the words of the law.

Besides, for the purposes of this piece of work, I followed, as Anna Odrowaz-Coates (2019) in the Introduction to this volume, Haidt \& Graham (2007) and Graham et al. (2009) in their categorization of a certain discourse as conservative or liberal. According to these authors, these political approaches can be differentiated by the orientation people express towards core values: liberally oriented people focus on the protection of human rights and individuality, whereas the conservatively oriented focus on binding people into groups and institutions (Odrowaz-Coates 2019).

\section{THEORETICAL FRAMEWORK}

As my perception of law and legal knowledge is significant for the analysis, I will briefly explain the theoretical background and the assumptions on which that analysis is based. To begin with, from a post-feminist approach (Hunt Federle 1993), an adequate rights theory must account for power. Power is the cause of social oppression and political inequality, for it implies hierarchy and status. Rights, however, mitigate the 
exclusionary effects of power by allowing the powerless to access existing political and legal structures in order to make claims. Permitting rights claims has the valuable effect of redistributing power and altering hierarchies.

The real value of rights lies in that point because rights require that we respect the marginalized, empower the powerless, and strengthen the weak. However, as long as we view children as undeveloped or underdeveloped beings evolving into adulthood, we can discuss individual rights only in terms of hierarchy and exclusion.

That is why, in my view, we can take lessons from the work of another subordinated group to help us understand the condition of childhood and how to amend it (Mayall 2000). Women over two centuries, and with considerable force in the last decades, have worked towards deconstructing the assumptions that lie beneath the dominant accounts.

The spaces and times of childhood are proposed as, ideally, protected from politics. Children are to be protected, in an a-political arena of thought and practice. Just as women have been assigned to the private and the domestic, so we are taught to think of children as growing up there too, far away from public life.

Additionally, I have a critical view of criminal law as a way to deal with conflict in society. Following Louk Houlsman (1986), I believe that "[c]rime has no ontological reality. Crime is not the object but the product of criminal policy. Criminalization is one of the many ways to construct social reality".

There are forms of human diversity which, in modern capitalist societies, are labeled and processed as criminal but which would not be subject to control in different societies. Other controls on "anti-social" behavior (and other definitions of what that might constitute) could be designed (Taylor, Walton \& Young 1974). What is more, the criminal justice system has always drawn its clientele mainly from the most disadvantaged sections of the population and still does so. Those who are officially recorded as "criminal" constitute only a small part of those involved in events that legally are considered to require criminalization. Among them, young men and women from the most disadvantaged sections of the population are heavily over-represented (Houlsman 1986).

That is why, for a meaningful approach to the Latin American context, I will consider intersectionality as both a theory to identify, analyze and articulate the complex social forces that influence the lives of young people in the region and as a practice to support their collective action in tackling the intersecting inequalities that they experience by virtue of their age and socio-economic class (Konstantoni \&Emejulu 2016). By “intersectionality”, I mean "the simultaneous and interacting effects of gender, race, class, sexual orientation, and national origin (and others) as categories of difference” (Bassel \& Emejulu 2010, 518).

\section{RESULTS}

Bill no. 22,278

Régimen Penal de la Minoridad is a short text: it has only twelve articles. The analysis of the vocabulary used in it shows a predictable result: $95.45 \%$ of the vocabulary was 
coded as related to the tutelary system and only $4.55 \%$ alludes to a child's rights approach (see graphic no. 1).

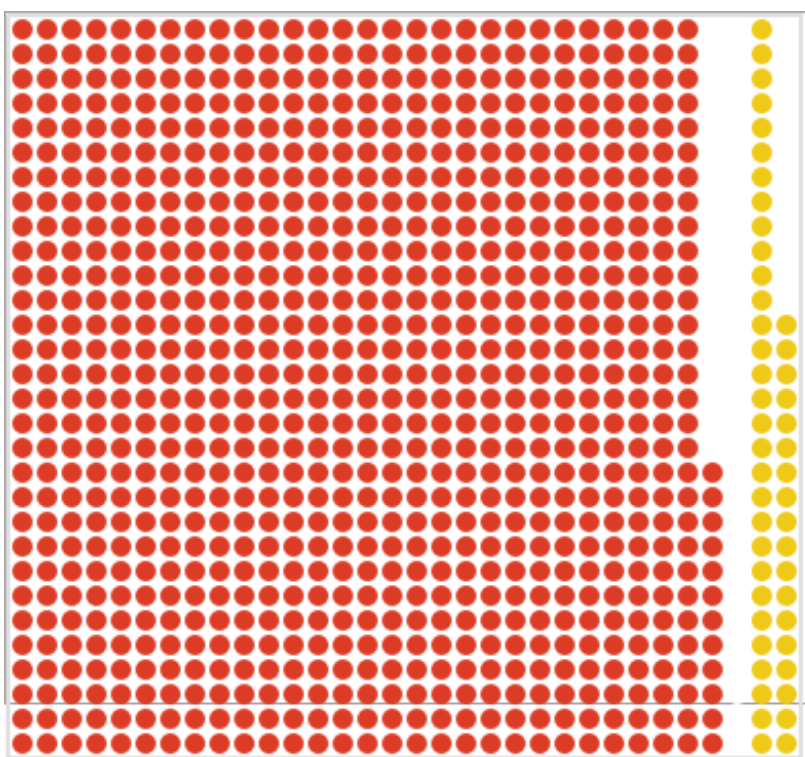

Graphic no. 1 - showing the segments coded as "Tutelary System" in the left (red tiles) and the segments coded as "Rights System" in the right (yellow tiles).

The bill refers to children as menores. This word appears nineteen times, in ten of the twelve articles that compose it. While the strict translation of this word in English would be minors, in the Latin American context it does not refer to children, in general, but to poor children who are in some kind of danger, because of their socio-economic vulnerability.

This bill and has no allusions at all to the right of children to be heard during the procedures. The system it creates gives judges the possibility to disponer definitivamente (institutionalize) children if they find that they are "abandoned, lacking assistance, in material or moral danger, or presenting behavioral problems" (article 2). In addition, there are no dispositions regarding educational or re-socializing measures.

Moreover, and in accordance to its -in theory-protective purposes, article 6 of the bill states that the custodial sentences on minors will be made effective in specialized institutes, separated from adults. It also establishes the minimum age of criminal responsibility (MACR) in sixteen years old. It does so by stating that minors between sixteen and eighteen years old will be punibles (punishable) if they commit a crime (Article 2).

\section{Sistema de Responsabilidad Penal Juvenil project}

The project sent to Parliament is a long text; it comprises one hundred articles and one annex. The analysis of the vocabulary used in the project shows that $67.31 \%$ is connected to the "Rights System", whereas 32.69 \% refers to the "Tutelary System" (see graphic no. 2). 


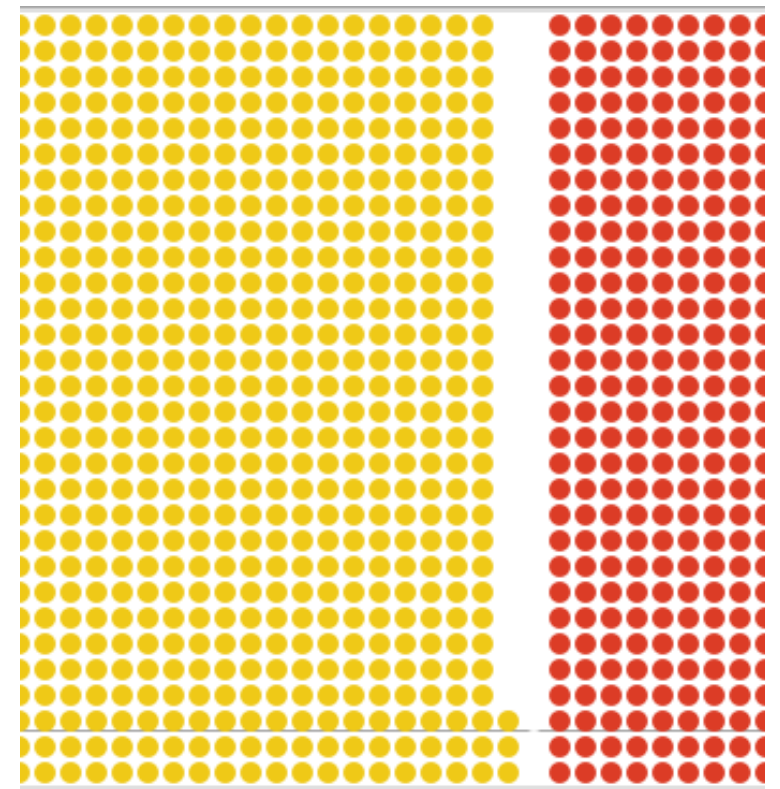

Graphic no. 2 - showing the segments coded as "Rights System" in the left (yellow tiles) and the segments coded as "Tutelary System" in the right (red tiles).

In clear opposition with the current bill, the project refers to the subjects of juvenile criminal system as adolescentes en conflicto con la ley penal (adolescents in conflict with criminal law) -instead of menores- while, when regulating the rights of children below the MACR, it speaks about "boys" and "girls".

The project enumerates a long list of rights that will be guaranteed to these adolescents: to privacy, to respect their best interest, to keep in contact with their families, to access to books, music and information, to receive job training and all the rights connected to the right to due process (Articles 6 to 14).

Some alternatives to imprisonment are contemplated e.g. to be obliged to offer a reparation to the victim and some socio-educative measures. These measures consist in participating in community programs and different types of training. Besides, the project also strongly states that life imprisonment will be prohibited for adolescents (Article 50).

The new system eliminates the possibility for judges to order institutionalization; in case they find that the adolescent does not have a family or, although having one, it represents a threat to his or her best interest, judges can order a provisional accommodation in a specialized institution (Article 30).

As the current bill, the project states that the custodial sentences will be made effective in particular institutions. However, there is one major difference between these two legal texts: the project establishes the minimum age of criminal responsibility in fifteen years old for serious crimes [4]. For minor crimes, the MACR remains in sixteen years old (Articles 2 and 14). 


\section{DISCUSSION OF RESULTS}

I will concentrate the discussion on three main aspects. The first one will be the resort to institutionalization of children as a way to deal with social conflict, the second will be the relation between vocabulary and ideology and, finally, I will make some remarks about the MACR.

To begin with, I would like to comment on the possibility of the state to institutionalize the child in case it is found that he or she does not have an adequate family or is perceived to be in some kind of danger. Even though the project establishes some limits to institutionalization and the right of the child to be heard during the procedures, this institution is making, at least, two assumptions. Furthermore, it is important to note this because " $[\mathrm{t}]$ exts inevitably make assumptions. What is 'said' in a text is 'said' against a background of what is 'unsaid' but taken as a given" (Fairclough 2003).

On one hand, under the humanist slogan of "taking the minor away from criminal law" (criminal law understood fundamentally in a retributive sense), the tutelary system was supposed to adopt protective and educational measures for the benefit of the youth that aimed at their rehabilitation (Beloff \& Langer 2015). These criminological trends are supported by the older and well-established idea in civil and common law countries that the state should act in loco parentis - that is, subrogating the parental functions- in cases in which the child did not have parents or the parents were considered incapable of carrying out their parental duties (Beloff \& Langer 2015). This regulation, which is clear in the current law and still present (though, mitigated) in the project, is associated with the concept of the child's need of protection and presupposes that children are vulnerable objects and not autonomous right bearers.

On the other hand, this emphasis on the importance of family is overlooking children's own perception as a social group (Mayall 2000) and the importance of their community of peers. It assumes that children are not part of society and that they should be kept out of it and it gives adults (families or the state) an enormous amount of power over them. This power is also shown by the creation of educative measures as sanctions. In a Child's Rights Approach, education should be a universal right for all children, not a sanction to impose in case they commit an offense.

Familiarization and individualization imply that where childhoods go wrong and deviate from norms, the problem and its cure are located at individual case level, rather than at socio-economic levels. Thus, children are understood as individuals within the family (rather than as a social group) and their success is deemed to depend on what the family provides. The child's development is seen as the product of individual relationships -rather than, for instance, of structural factors (Mayall 2000). What is more, in the Latin American context, structural factors refer to socio economic conditions of poverty which is the main reason why children are without adult supervision or in danger.

The second aspect I would like to point out is the relation between vocabulary and ideology. The project manifestly uses a vocabulary that relates to human rights discourse in a strong manner. Not using the word menor anymore is a demonstration of the intention to differentiate from the Tutelary System. As I have mentioned above, 
menores is the word used by public institutions in the Tutelary System to imply a category of vulnerable children, because of their social or familiar situation. It does not refer to children as a universal category but to children who live in the street, are alone or poor. This category has a strong relation with socio-economic structures as it implies the criminalization and institutionalization of poverty.

In this regard, it is interesting to point out that, in Spanish, the word menor has also another meaning. It refers to "something which is inferior to something else in quantity, intensity or quality" [5]. This meaning denotates, again, the power relations that are present and assumed in the legal text, naturalizing the domination over (poor) children, who are perceived as inferiors.

However, the chosen word adolescentes (adolescents) shows the authority of adult world over children, once more. The concept of adolescence (itself an adult construction, and not a term used by young people themselves) extends beyond childhood the idea that young people are human becomings, rather than people (Erikson 1965) and shows that they are not still ready to fully exercise their rights as human beings and their citizenship.

In addition to this, the long list of rights that adolescents in conflict with the law are supposed to have under this new legislation is a clear intent to demonstrate the state's affiliation with a liberal, human rights' discourse. This can be seen in the intertextuality relation between the project and the CRC: all the articles containing rights for adolescents in conflict with the law are copied from the text of Convention.

Moreover, this enumeration of rights was unnecessary. Children are human beings and that, in a liberal society that is - allegedly - devoted to human rights' protection, should be enough to guarantee their right to, for instance, access to information.

Similarly, intertextuality relations are also present in the prohibition to sentence a child to life imprisonment stated in the text of the project. This statement relates to texts produced by of two important human rights bodies: The International Committee on the Rights of the Child and the Inter-American Court of Human Rights. The Committee has stated many times in its reports on states, and now in the new general comment, that no child who was below the age of 18 at the time he or she committed an offence should be sentenced to life imprisonment without the possibility of release or parole (Committee on the Rights of the Child 2019). Furthermore, as mentioned before, the Inter-American Court of Human Rights had commanded Argentina in re Mendoza that the state should change its legislation regarding this issue.

Both the vocabulary used in the project and the intertextuality relations exposed above, seek to demonstrate the government's commitment to Human Rights Discourse and its intention to achieve legitimacy. Also, they show the state's willingness to follow the international institutions recommendations.

However, and this leads to the last aspect I would like to discuss, the project establishes a MACR of fifteen years old for serious crimes. First of all, lowering the MACR is a retrogressive measure. According to the Committee on the Rights of the Child (2019), those states having provisions that are more conducive to the rights of children than those contained in the CRC should not take any retrogressive steps, as article 41 of the CRC states. 
Once again, this has a particular effect in the Argentine context. Juvenile institutions are very similar to adult correctional facilities and the conditions in which imprisoned children live are, in most cases, inhumane and constitute a violation of the rights established in the CRC.

In addition to this, lowering the MACR is also a deceptive measure, since the problem of the involvement of children and adolescents with crime would not probably be solved by it. Actually, one of the outcomes may be the co-optation of increasingly younger children and adolescents by criminal organizations (De Melo Resende 2009) in order to avoid prosecutions.

The necessary relationship between the marginalization of adolescents and the socioeconomic exclusion of their families -to which I referred before- and the social precariousness and the lack of services is not addressed. Lowering the age of criminal responsibility is not about solving the problem of urban violence in the country, it is about criminalizing poverty, and hiding it behind Human Rights discourse.

Finally, because I cannot go any further on this topic here, this measure was probably designed to respond to public pressure. In accordance with a Child's Rights approach the state should set one standardized age below which children cannot be held responsible in criminal law, without exception. Once again, as Alessandro Baratta has argued, criminal law (understood as punitive power) is certainly not an "equal" law (Baratta 2001).

\section{CONCLUSION}

A comprehensive liberal discourse on children in conflict with the law would propose that all juvenile law is abolish. If we want to take children`s rights seriously we should question why we need a specialized criminal system and, instead, we should develop a restorative justice system that focuses on the pedagogical potential of the procedures, respecting the rights of children to participate in the proceedings. And this potential is not only important for children but, because children are a social group, it would be relevant for society as well.

A liberal, children's rights, approach would not be directed to treat children as adults, by lowering the MACR and sending them into the criminal system. It will engage in protecting and accompanying them so they can achieve their highest potential while they gain experience in public and social matters. This approach would have strong socio-economic consequences and it will require a public debate about making economic resources available for children and a new understanding of citizenship.

However, more critical studies on children's rights and children in conflict with the law are needed in Latin America, specially to determine the influence of the media and the official discourse on the society's perception of young delinquents.

Changes are always good opportunities. Moreover, the debate about children in conflict with law is urgent and cannot be postponed. We, as adults, have the possibility to reconfigure the relation between our judicial institutions and childhood. This opportunity will be missed, once again, if this project is accepted and it will represent a retrogressive step towards a discourse that is even more conservative than the tute- 
lary system discourse.

\section{NOTES}

[1] All translations were done by the author.

[2] The doctrine of de facto governments is a doctrine of jurisprudential origin developed by the Supreme Court of Justice of Argentina to validate the normative acts of military dictatorships that were installed in the country during the twentieth century and thereby legitimize them.

[3] The Argentine Supreme Court has adopted a monistic position towards international human rights law. This implies the existence of a single legal system. In case of conflict between constitutional law and national laws, the first one prevails. As the CRC is part of the National Constitution (by its article 75.12 ), it has priority over bill no. 22,278, which is domestic law. [4] "Serious crimes" refers to crimes sanctioned with twenty five of fifteen years of imprisonment.

[5] According to Diccionario de la Real Academia Española available at https://dle.rae. es/srv/search?w=menor

FUNDING: This research was funded by the UNESCO/Janusz Korczak Chair fellowship 2019 obtained through the Polish Commission for UNESCO

CONFLICT OF INTEREST: The author declares no conflict of interest.

\section{REFERENCES}

Argentina. Base general de datos de niños, niñas y adolescentes. Informe de 2016, https://www.csjn.gov.ar/bgd/verMultimedia?data=1430

Argentina. Base general de datos de niños, niñas y adolescentes. Informe de 2017, https://www.csjn.gov.ar/bgd/verMultimedia?data=2210

Argentina. Base general de datos de niños, niñas y adolescentes. Informe de 2018, from https://www.csjn.gov.ar/bgd/verMultimedia?data=2210

https://www.csjn.gov.ar/bgd/verMultimedia?data=3110

Argentina. Exposición de motivos, https://www.justicia2020.gob.ar/eje-penal/sistema-penal-juvenil/

Baratta, Alessandro. 2001. Criminología crítica y crítica del derecho penal. Introducción a la sociología jurídico penal. Translated by Búnster, A. Buenos Aires: Siglo XXI.

Bassel, Leah and Emejulu Akwugo. 2014. "Solidarity Under Austerity: Intersectionality in France and the United Kingdom.” Politics \& Gender 10(1): 130-136.

Beloff, Mary and Langer Máximo. 2015. "Myths and Realities of Juvenile Justice in Latin America.” Pp. 198-248 in Juvenile Justice in Global Perspective, edited by F. Zimring, M. Langer \& D. Tanenhaus. New York and London: New York University 
Press.

Committee on the Rights of the Child. 2019. General comment No. 24 on children's rights in the child.

De Melo Resende, Viviane. 2009. “Dessemelhanca e expurgo do outro no debate acerca do rebaixamento da maioridade penal no brasil: uma análise discursiva crítica.” Forma y Función 22(1): 145-159.

Donaldson, Sue and Will Kymlicka. 2016. "Rethinking Membership and Participation in an Inclusive Democracy” in Disability and Political Theory, edited by B. Arneil and N. Hirschmann. Cambridge: Cambridge University Press.

Emejulu, Akwugo and Kristina Konstantoni. 2016. "When intersectionality met childhood studies: the dilemmas of a travelling concept.” Children's Geographies: 15(1): $1-17$.

Erikson, Erik. 1965. Childhood and Society. Harmondsworth: Penguin.

Fairclough, Norman. 2003. Analyzing Discourse. London and New York: Routledge.

Graham, Jesse, Jonathan Haidt and Brian Nosek. 2009. "Liberals and conservatives rely on different sets of moral foundations." Journal of Personality and Social Psychology 96 (5): 1029-1046.

Haidt, Jonathan and Jesse Graham. 2007. "When morality opposes justice: conservatives have moral intuitions that liberals may not recognize.” Social Justice Research 20: 98-116.

Hunt Federle, Katherine. 1993. “On the Road to Reconceiving Rights for Children: A Postfeminist Analysis of the Capacity Principle.” DePaul Law Review 42(3): 9831028.

Hulsman, Louk H. C. 1986. “Critical criminology and the concept of crime.” Crime, Law and Social Change 10(1): 63-80.

Inter-American Court of Human Rights. Mendoza and others $v$ Argentina. Judgment of May 14th, 2013. (Preliminary Objections, Merits and Reparations).

Mayall, Berry. 2000. “The sociology of childhood in relation to children's rights." The International Journal of Children's Rights 8: 243-259.

Niemi-Kiesilainen, Johanna, Paivi Honkatukia and Minna Ruuskanen. 2007. "Legal Texts as Discourses” in Exploiting the Limits of Law, edited by A. Gunnarsson, E. Svensson \& M. Davis. Hampshire: Ashgate.

Odrowaz-Coates, Anna. 2019. “Gender equality and children's equality in liberal and conservative discourses. Implications towards language and society.” Society Register 3(4): 1-11.

Steiner, Gary. 2013. Animals and the Limits of Postmodernism. New York: Columbia University Press.

Taylor, Ian, Walton, Paul and Young, Jock. 1974. "Advances towards a critical criminology.” Theory and Society 1(4): 441-476.

United Nations Office of the High Commissioner on Human Rights. 2018. Committee on the Rights of the Child considers report of Argentina. Available, from https://www.ohchr.org/EN/NewsEvents/Pages/DisplayNews.aspx?News$\mathrm{ID}=23088$ \&LangID $=\mathrm{E}$ 


\section{TEXTS ANALYZED}

Bill no. 22.278. Régimen Penal de la Minoridad (minority criminal regime), from http:// servicios.infoleg.gob.ar/infolegInternet/anexos/110000114999/114167/texact. htm

Project of a Bill Sistema de Reponsabilidad Penal Juvenil (juvenile justice responsibility system) presented on March $1^{\text {st }}$, 2019, from https://www.diputados.gob.ar/prensa/noticias/noticias-podio/noticias_0912.html

\section{BIOGRAPHICAL NOTE}

Yamila Vanessa Rodriguez, MA, Department of Law, University of Buenos Aires in Argentina. She is a lawyer and children's rights activists.

OPEN ACCESS: This article is distributed under the terms of the Creative Commons Attribution Non-commercial License (CC BY-NC 4.0) which permits any non-commercial use, and reproduction in any medium, provided the original author(s) and source are credited.

ARTICLE HISTORY: Received 2019-09-29 / Accepted 2019-11-27 
